\title{
Housing the Citizen-Consumer in Post-war Britain: The Parker Morris Report, Affluence and the Even Briefer Life of Social Democracy
}

\begin{abstract}
:
This article examines debates about the design and provision of post-war housing within the papers and report of the Parker Morris committee. It does so in order to show how the models of citizens' rights and expectations which underpinned post-war welfare provision were transformed by mass affluence and the dynamic sphere of commercial consumption. Parker Morris's deliberations demonstrate that, as early as the 1950s, the citizen-subject was reimagined as a consuming individual, with requirements based on their expressive needs and consuming desires, and that this had far-reaching consequences for social democratic systems of universal welfare provision. The introduction of consumerist imperatives into publicly-defined models of citizens' needs enhanced the political and cultural authority of the commercial domain, prompted a heightened role for commercial experts and market logics within public governance, and served to devalue socialised forms of provision in favour of consumer choice in the private market. The article thus engages with the growing scholarship on the politics of mass consumerism by showing how the material and emotional comforts of post-war affluence came to be constructed as critical to social democratic citizenship and selfhood. Situating this uneasy entanglement of social democratic rights with consumer satisfaction as part of a wider trajectory of political change, the piece suggests that Parker Morris marks an early but significant moment in the transition from post-war welfarism and social democracy to the consumer- and market-oriented forms of governance which came to dominate British politics and society in the latter part of the twentieth century.
\end{abstract}

\section{Keywords:}

Affluence; Housing; Post-war Britain 


\section{Introduction}

In 1958, the Conservative Minister of Housing and Local Government, Henry Brooke, commissioned Sir Parker Morris to undertake a review of housing standards in England and Wales. ${ }^{1}$ From the outset, the committee was directed to address 'the steady rise in real incomes and the new pattern of living which has arisen with it', which had found expression in 'buying things for the home and generally living to a higher standard'. ${ }^{2}$ Rising wages and additional income from working mothers, the spread of television and car-ownership, vigorous demand for consumer durables and spending on home furnishings, and the need to accommodate 'the teenager', were flagged up by the Ministry as starting points for enquiry. ${ }^{3}$ The committee's task then, was to ascertain the impact of post-war social and economic change on the nature and experience of the British home, and to suggest amendments to housing standards which would respond to what were perceived as the new demands of an affluent, 'home-centred society' and a mass-consuming citizenry. In many ways, Parker Morris's committee rose admirably to this task. The nineteen members were drawn from across the public and private housing and building sectors, with a diverse professional make up, strong contingents of women, architects, and local authority figures, and representation from the public health and social work professions. ${ }^{4}$ The committee undertook two years of information gathering and analysis, met twenty-four times (often for two days), visited over 600 houses in New Towns, council estates and private developments across the country, and took evidence from a prodigious array of over eighty different actors and institutions. Public sector experts such as planners, health professionals and local authority housing officials made representations, but so too did house-builders, building societies, women's groups, housing charities, and a plethora of commercial and trade bodies such

\footnotetext{
${ }^{1}$ Parker Morris was a trusted member of the Ministry's standing Central Housing Advisory Committee (CHAC), former clerk of Westminster City Council, and Chair of the National Federation of Housing Societies. ${ }^{2}$ The National Archives: Public Record Office, Kew [TNA:PRO], Ministry of Housing and Local Government [HLG], 37/112, 'H.S.1: Background Paper', Parker Morris Committee [PMC] Working Paper, Jan 1959, 1.

${ }^{3}$ TNA:PRO, HLG, 37/112, 'H.S.1: Background Paper', PMC Working Paper, Jan 1959, 1-2.

${ }^{4}$ Full details of members' backgrounds and appointment in TNA:PRO, HLG, 37/111.
} 
as the British Refrigeration Association, the Furniture Development Council, and the Institute of British Launderers. ${ }^{5}$

The resulting report, Homes for Today and Tomorrow, which was published in 1961, is best remembered for producing a set of generous minimum space standards in public housing, intended to ensure that all state-provided housing was of adequate size and design to accommodate 'the new pattern of living' associated with mass affluence. ${ }^{6}$ Both in academic accounts and in popular memory, Parker Morris thus often stands as emblematic of the collective welfare guarantees of the social democratic state. In this vein, one housing policy analyst writing in 1979 called the report 'the most enlightened state paper on housing published since the war', and the Parker Morris standards continue to be invoked by politicians and commentators as an exemplar of progressive and equitable state regulation. ${ }^{7}$ Correspondingly, the abandonment of Parker Morris standards under the first Thatcher government in 1981 is sometimes ascribed totemic significance, as a milestone in the turn away from socialised housing and post-war welfarism and towards neoliberal governing rationalities and marketised systems of social provision. Alison Ravetz describes the 'termination of Parker Morris standards' as the 'abandonment of an ideal', and Mark Clapson writes that it marked 'the end of an era of collective housing, ${ }^{8}$

\footnotetext{
${ }^{5}$ See Appendix 9, Ministry of Housing and Local Government, Homes for Today and Tomorrow (London, 1961). Hereafter MHLG, Homes.

${ }^{6}$ See Alison Ravetz, Council Housing and Culture: The History of a Social Experiment (London, 2001), 97-98; John Burnett, A Social History of Housing 1815-1985 (London, 1986), 305-308.

${ }^{7}$ Stephen Merrett, State Housing in Britain (London, 1979), 104. For recent commentary see Owen Hatherley, 'If We Don't Want to Live in Shoeboxes, We Need to Bring Back Housing Standards', The Guardian, 7 January 2014; 'Architects Beginning to Think Big', The Independent, 14 October 2010; Rory Olcayto, 'Boris Pledges to Reinstate Parker Morris Standards', Building, 27 June 2008.

${ }^{8}$ Ravetz, Council Housing, 191; Mark Clapson, Routledge Companion to Britain in the Twentieth Century (Abingdon, 2009), 45.
} 
The Parker Morris report was undoubtedly suffused with an idealistic intent to guarantee a comfortable and pleasant standard of housing for all, and, as such, did represent a particularly ambitious and optimistic moment in the post-war trajectory of welfare provision. Its effects as a piece of policy, however, were rather more ambiguous. The standards were never applied to the booming private sector, and, although the impetus from the report's publication reversed the 1950s trend for shrinking house sizes in the public sector, Brooke's Ministry refused to prescribe the costly recommendations for state-provided housing. ${ }^{9}$ Parker Morris standards were made mandatory in New Town and local authority housing by Harold Wilson's government, in 1967 and 1969 respectively. By the late-1960s however, insisting on the irreducible minima of Parker Morris in the face of inflation, higher building costs, and severe restrictions on housing budgets forced local authorities into impossible dilemmas. The standards were met by scrimping and saving elsewhere on materials and design, by building less, and by turning to cheap, industrialised building methods which often produced unpopular housing with limited lifespans. ${ }^{10}$ We might read the fraught implementation of Parker Morris then, as an indication of the basic political tensions at the height of the supposed social democratic consensus-particularly in the arena of housing — in which many on the right remained decidedly unconvinced about collective provision, and many on the left struggled with the consistent mismatch between welfarist aspirations and the national balance sheet. ${ }^{11}$

\footnotetext{
${ }^{9}$ Peter Malpass \& Alan Murie, Housing Policy and Practice (Basingstoke, 1994), 76; D.V. Donnison, The Government of Housing (Harmondsworth, 1967), 159-160.

${ }^{10}$ Burnett, Social History of Housing, 314; Merrett, State Housing, 105; A.E. Holmans, Housing Policy in Britain; A History (London, 1987), 121; Anne Power, Property Before People: The Management of TwentiethCentury Council Housing (London, 1987), 60-61.

${ }^{11}$ On the contentious position of housing within the post-war settlement see Peter Malpass, 'The Wobbly Pillar? Housing and the British Postwar Welfare State', Journal of Social Policy 32:4 (2003), 589-606; Harriet Jones, “"This is Magnificent!”: 300,000 Houses a Year and the Tory Revival after 1945', Contemporary British History 14:1 (2000), 99-121; Peter Weiler, 'The Rise and Fall of the Conservatives' "Grand Design for Housing”, 1951-64', Contemporary British History 14:1 (2000), 122-150.
} 
This article also uses Parker Morris to unpick some of the political and ideological tensions at the heart of the post-war settlement, but it does so from a slightly different perspective. The debates about the design, function and provision of housing are used here to demonstrate the extent to which affluence and mass consumerism were transforming established models of the citizen-subject by the late-1950s, and to highlight some of the implications of this for modes of governance and welfare, and for the relationship between the state and the individual. In their efforts to regulate domestic space and experience, the Parker Morris committee recast the recipient of housing policy as a consuming individual, and mapped consumerist and highly-individualist models of the citizen-subject onto the spaces and technologies of the post-war home. Crucially, this entailed a re-imagining of citizens' rights and expectations in terms of their consuming desires, and a growing acceptance of public responsibility for individuals' expressive needs. A heightened emphasis on the home as a site of personal consumption prompted a greater role for commercial experts and market logics within the structures of public governance, and produced new ways of classifying and regulating individuals in the domestic setting. The article shows that housing officials and experts in the post-war period increasingly concerned themselves with the psychological needs of the citizen in their home, and these needs were understood to hinge on self-actualisation via the commerciallyorchestrated world of consumer goods.

The discussion therefore builds upon the growing recognition that 'affluence and welfare were intimately connected, not discrete categories'. ${ }^{12}$ Work in this vein has tended to develop along one of two lines. The first has been to draw attention to the function of welfare states' guarantees of living standards, socialised services, and pursuit of full employment in

\footnotetext{
${ }^{12}$ Simon Gunn, 'European Urbanities since 1945: A Commentary', Contemporary European History 24:4 (2015), 617-622, 621.
} 
underpinning the unprecedented material prosperity of the post-war decades. ${ }^{13}$ From this perspective, the collective security of welfare encouraged and facilitated the emergence of an affluent, mass consuming, and increasingly-individualistic society. ${ }^{14}$ A second line of enquiry has focused on the dynamic and symbiotic relationship between models of citizenship and of the consuming subject. Frank Trentmann has traced a story of consumption and politics in Britain across the twentieth century in which consumers 'have been active constituents of political economy', helping to define norms of citizenship and governance through their politics, practices, and purchases. ${ }^{15}$ Peter Gurney suggests that, from the 1950s, 'the atomized figure of the individual consumer began to exert a hegemonic influence across both polity and civil society, shaping the epistemologies and languages through which the political and economic domains were thought and represented'. ${ }^{16}$ Frank Mort has also highlighted the specific entanglement of 'the agendas and rhetorics of democracy and consumerism' at the height of post-war consumer expansion, and in the ideologically-charged context of the Cold War. ${ }^{17}$

This article examines the mutual constitution of the categories of 'citizen' and 'consumer' in one important area of post-war social policy: housing. It does so in order to add empirical

\footnotetext{
${ }^{13}$ Frank Trentmann, Empire of Things: How We Became a World of Consumers, from the Fifteenth Century to the Twenty-First (London, 2016), esp. 12-13.

${ }^{14}$ Emily Robinson, Camilla Schofield, Florence Sutcliffe-Braithwaite \& Natalie Thomlinson, 'Telling Stories about Post-war Britain: Popular Individualism and the "Crisis" of the 1970s', Twentieth Century British History (2017), 1-37; Avner Offer, 'British Manual Workers: From Producers to Consumers, c.1950-2000', Contemporary British History 22:4 (2008), 537-571.

${ }^{15}$ Frank Trentmann, 'Bread, Milk and Democracy: Consumption and Citizenship in Twentieth-Century Britain', in Martin Daunton \& Matthew Hilton (eds.), The Politics of Consumption: Material Culture and Citizenship in Europe and America (Oxford, 2001), 129-164, 131. See also Matthew Hilton, Consumerism in TwentiethCentury Britain: The Search for a Historical Movement (Cambridge, 2003).

${ }^{16}$ Peter Gurney, 'The Battle of the Consumer in Postwar Britain', Journal of Modern History 77 (2005), 956987, 959.

${ }^{17}$ Frank Mort, 'Competing Domains: Democratic Subjects and Consuming Subjects in Britain and the United States since 1945', in Frank Trentmann (ed.), The Making of the Consumer: Knowledge, Power and Identity in the Modern World (Oxford, 2006), 225-248, 226.
} 
depth to our understanding of how precisely the figure of the consumer reshaped the epistemologies and languages of post-war politics, by tracing the historical manifestations of this in governmental discourse, policy-making, and welfare provision. In the absence of more detailed empirical study into how ideas of the citizen-subject came to be transformed by consuming practices, we know relatively little of the historical processes through which models of the citizen and consumer were elided, how (or where) such a recasting of the individual subject took place, and what the implications of this were for existing forms of public provision, and for the relationship between the state, the market, and the individual. Building on these concerns, the article places Parker Morris's alignment of social democratic citizenship with consumerist imperatives of self-expression and market choice within a broader trajectory of political change across the second half of the twentieth century. James Vernon has recently suggested that understanding and historicising 'the brief life of social democracy' is 'the central historical problem in twentieth-century Britain', and much recent scholarship has sought to complicate the conventional chronological transition from post-war social democracy to latetwentieth-century neoliberalism via a 1970 s crisis and Thatcherite rupture. ${ }^{18}$ Parker Morris shows that, as early as the 1950s, the commercial logics of mass consumerism were transforming models of citizenship and welfare in ways which enhanced the political and cultural authority of the commercial domain, and served to devalue socialised forms of provision in favour of consumer choice in the private marketplace. Indeed, the case shows how social democratic aspirations to guarantee the material and psychological well-being of each individual morphed into consumer- and market-oriented forms of governance under the influence of affluence and the dynamism of the commercial-cultural sphere of personal consumption.

\footnotetext{
${ }^{18}$ See Vernon's contribution to 'Roundtable: Twentieth-Century British History in North America', Twentieth Century British History 21:3 (2010), 375-418, 418.
} 


\section{Homes for Consuming Heroes}

Increased spending on the home was one of the most striking patterns of post-war consumerism. As Trentmann notes, in the middle of the twentieth-century, 'the home became the single largest consumer good in people's lives'. ${ }^{19}$ This was most obviously the case for homeowners, whose numbers, by the time Parker Morris reported, had been substantially boosted by ten years of Conservative housing policies and mortgage subsidies aimed at establishing a 'property-owning democracy'. ${ }^{20}$ The proliferation of spending on the home was by no means limited to owner-occupiers however. Ferdynand Zweig’s 1961 study of workers'spending patterns across housing tenures concluded that 'most of the spare money of these people is spent on the home', and subsequent historical research substantiates the contemporary sociological view that spending on and for the home intensified significantly across social classes and tenures. ${ }^{21}$ Indeed, for Zweig and other social investigators concerned with the rise of the affluent worker, it was shifting patterns of domesticity—the rise of home-based leisure and consumption, growing privatism, and a focus on family life — which defined the demands and outlook of this 'new' social actor. In 1959, the year Parker Morris's committee began its work, the social and market researcher Mark Abrams propounded the new values of 'the home-centred society' in the pages of The Listener, based on domestic comfort, consumption, and leisure across classes. ${ }^{22}$ The contemporary resonance of such ideas entered into the thinking of the Parker

\footnotetext{
${ }^{19}$ Trentmann, Empire of Things, 236.

${ }^{20}$ On Conservative housing policy and thinking see Weiler, 'Rise and Fall'; Matthew Francis, “'A Crusade to Enfranchise the Many": Thatcherism and the "Property-Owning Democracy", Twentieth Century British History 23:2 (2012), 275-297.

${ }^{21}$ Ferdynand Zweig, The Worker in an Affluent Society: Family Life and Industry (London, 1961), 10. For contemporary surveys see Dennis Chapman, The Home and Social Status (London, 1955); R. Wilkinson, 'A Survey of Slum Clearance Areas in Leeds', Urban Studies 2:1 (1965), 1-14. For discussion see Sue Bowden \& Avner Offer, 'Household Appliances and the Use of Time: The United States and Britain since the 1920s', Economic History Review 47:4 (1994), 725-748; Burnett, Social History of Housing, 281-285.

${ }^{22}$ For discussion see Clare Langhamer, 'The Meanings of Home in Postwar Britain', Journal of Contemporary History 40:2 (2005), 341-362.
} 
Morris committee and those who gave evidence. The Society of Medical Officers of Health, for example, began its submission to Parker Morris on a contemplative note, suggesting that 'the philosophic concepts governing the present British way of life...clearly involve in their application an overwhelming demand for the material products of this mechanistic age, ${ }^{23}$ The Town and Country Planning Association pointed out that 'people [were] seeking to make their homes places of recreation and entertainment...they stay at home to watch television and play records'.$^{24}$

Despite contemporaries' sense that the home-centred society and the affluent worker were novel phenomena in the post-war era, there is ample historical evidence that such models of affluence, in Jon Lawrence's words, 'misread the cultural changes of the early 1960s as the product of sudden social and economic change, ${ }^{25}$ Lawrence suggests that it was social investigators' lack of attention to the substantial improvements in living conditions for many interwar workers which led them to such conclusions, and studies by Peter Scott and Judy Giles effectively demonstrate that aspirational, home-centred lifestyles based on improved housing, home-ownership and consumerism were well within the reach of many in the 1920s and 1930s. ${ }^{26}$ Although affluent domesticity was not completely novel to the post-war working classes, the scale and intensity of such trends nonetheless increased in the 1950s, as unprecedented increases in real wages extended popular access to new standards of domestic leisure and comfort. ${ }^{27}$

${ }^{23}$ TNA:PRO, HLG, 37/148, Evidence of Society of Medical Officers of Health [SoMOH], September 1959, 3. Local Medical Officers of Health were responsible for designating slum housing as well for public health and environmental standards more generally.

${ }^{24}$ TNA:PRO, HLG, 37/143, Evidence of TCPA, August 1959, 1.

${ }^{25}$ Jon Lawrence, 'Class, “Affluence” and the Study of Everyday Life in Britain, c. 1930-1964', Cultural and Social History 10 (2013), 273-299, 288.

${ }^{26}$ Peter Scott, The Making of the Modern British Home: The Suburban Semi and Family Life between the Wars (Oxford, 2013); Judy Giles, The Parlour and the Suburb: Domestic Identities, Class, Femininity and Modernity (Oxford, 2004).

${ }^{27}$ Figures on real wage growth in the 'Golden Age' in Nicholas Crafts, 'The British Economy', in Francesca Carnevali \& Julie-Marie Strange (eds.), Twentieth-Century Britain (London, 2014), 7-25, 16. 
Whether or not their perceptions of the trends were entirely accurate, the Parker Morris committee was highly responsive to what they saw as radical changes in home life which had taken place since the war. On its opening page, the report's authors stated that:

Since the end of the war, the country has undergone a social and economic revolution... One household in three has a car; the same proportion have a washing machine. Television sets are owned by two households in three; so are vacuum cleaners; and one household in five has a refrigerator. These possessions are spreading fast through all income groups, fastest of all in the lower brackets. ${ }^{28}$

It was the extent and scale of affluent living in 'the lower brackets' which most impressed contemporaries in the 1950 s, and the dramatic take-up of new consumer durables was seen as a key indicator of this 'revolution'. While the Parker Morris committee were investigating, a short economic boom between 1958 and 1960 had seen the country go on 'a refrigerator spending spree', and figures for a whole range of consumer goods-televisions, washing machines, refrigerators, vacuum cleaners, hair dryers and toasters—show that the ten years from 1953 to 1963 witnessed the most dramatic increases in levels of ownership. ${ }^{29}$ The Ministry of Power's statistics indicate that domestic sales of electricity—on which many of the new appliances depended—doubled between 1948 and $1958 .^{30}$ The growing ubiquity of these domestic patterns of consumption shaped Parker Morris's thinking, and the committee recognised that such lifestyles were now a legitimate expectation on the part of those living in cheaper housing and in local authority homes. Yet their response was not simply to recommend more space to house the paraphernalia of affluence. Rather, the authors recognised that the post-war home must also perform a psychological function for the individual:

There was a time when for a great majority of the population the major significance of the structure in which they made their home was to provide shelter and a roof over their head. This

\footnotetext{
${ }^{28}$ MHLG, Homes, 1-2.

${ }^{29}$ Alistair Horne, Harold Macmillan: Vol. II 1957-1986 (Harmondsworth, 1989), 237; Bowden \& Offer, 'Household Appliances', Table A1; Burnett, Social History of Housing, 283; TNA:PRO, HLG, 37/142, Evidence of Institution of Electrical Engineers, May 1959, 7.

${ }^{30}$ TNA:PRO, HLG, 37/142, Evidence of Institution of Electrical Engineers, May 1959, 8.
} 
is no longer so. An increasing proportion of people are coming to expect their home to do more than fulfil the basic requirements. It must be something of which they can be proud; and in which they must be able to express the fullness of their lives. ${ }^{31}$

This model of the home as a space in which individuals could 'express the fullness of their lives' indicates a recognition within public governance that all citizens could now expect to use their home as a fulfilling and emotionally-satisfying site of leisure and consumption. Many of Parker Morris's respondents emphasised this point. Leeds's Housing Committee, for example, stressed that 'more leisure time' and 'modern household equipment' meant that the aim of any regulations should be to ensure that 'the house can become a home in the most comprehensive sense'. ${ }^{32}$ The committee members themselves were adamant that the report led with this 'more than a shelter' idea. They insisted that the final wording used the word 'home' rather than 'dwelling', and foregrounded the fact that 'one's home is an immensely precious experience to most people and it conjures up an immediate emotional - and even spiritual - response. ${ }^{33}$ The identification of home with individual selfhood and emotional satisfaction was not unique to the post-war period. Historians, sociologists and anthropologists have provided rich studies of the social and psychological significance of the home as a site in which the material and symbolic are brought together and individuals invest meaning in their domestic space and possessions. ${ }^{34}$ Recent work by Matthew Thomson and Michal Shapira has also shown that psychologised models of the individual subject and their emotional needs entered into public discourse in the interwar period and were powerfully present in the Beveridgean moment of post-war

\footnotetext{
${ }^{31}$ MHLG, Homes, 3.

32 TNA:PRO, HLG, 37/127, Evidence of City of Leeds Housing Committee [LHC], January 1960, 3.

${ }^{33}$ TNA:PRO, HLG, 37/203, Letter from Peter Chamberlin to Parker Morris, 30 January 1961, 1 \& 'Discussion of Chamberlin's letter'.

${ }^{34}$ See for example, Julie-Marie Strange, 'Fatherhood, Furniture and the Inter-Personal Dynamics of WorkingClass Homes, c. 1870-1914', Urban History 40:2 (2013), 271-286; Giles, Parlour and the Suburb; Tony Chapman \& Jenny Hockey (eds), Ideal Homes? Social Change and Domestic Life (London, 1999); Graham Allan \& Graham Crow (eds), Home and Family: Creating the Domestic Sphere (Basingstoke, 1989); Alison Blunt \& Robyn Dowling, Home (Oxford, 2006); Daniel Miller (ed.), Home Possessions: Material Culture Behind Closed Doors (Oxford, 2001).
} 
reconstruction and welfare. ${ }^{35}$ By the late-1950s however, the personal and psychological fulfilment of individuals was being linked explicitly with their ability to engage with commercial cultures of domestic consumption. Parker Morris's account of the basic domestic needs of married couples is instructive:

The living area must accommodate activities ranging from entertaining, watching television, or sewing and mending and hobbies, to writing letters, reading and relaxing. Space must be provided for two easy chairs, a settee, a low small table and a television set, and places suitable for a reasonable quantity of other possessions such as sewing box, radiogram and bookcase. ${ }^{36}$

This new public emphasis on the personal needs of the consuming individual conflicted with, and reformulated, pre-established notions of domestic privacy and of the family. The growth of a family-centred lifestyle was a key component of contemporary social investigators' understandings of post-war social change, and designing 'homes for family needs' was central to the way the Parker Morris committee understood their task. ${ }^{37}$ Yet the committee's papers reveal that by the late-1950s tensions had emerged between the notion of the family as a cohesive unit, which required privacy from the 'public' world beyond the front door, and a model of the family as an assemblage of individuals, who required space in which to enjoy privacy from each other. The Housing Centre Trust (a third sector organisation concerned with social housing), for example, reported that it was 'concerned at the lack of privacy in modern small houses for individuals in the household... Parents should... be able to have some privacy from younger children, men from women, and so on' ${ }^{38}$ Manchester's Housing Department framed 'privacy' in terms of individuals' need for space to engage in personalised consumption: 'increased leisure time must be catered for [and] the increased cultivation of hobbies may demand the provision of

\footnotetext{
${ }^{35}$ Matthew Thomson, Psychological Subjects: Identity, Culture and Health in Twentieth-Century Britain (Oxford, 2006); Michal Shapira, The War Inside: Psychoanalysis, Total War, and the Making of the Democratic Self in Postwar Britain (Cambridge, 2013).

${ }^{36}$ MHLG, Homes, 12-13.

${ }^{37}$ MHLG, Homes, 7.

${ }^{38}$ TNA:PRO, HLG, 37/138, Evidence of Housing Centre Trust [HCT], N.d. [1959?], 2.
} 
additional space'. ${ }^{39}$ The city's housing officials felt that these individualised leisure habits meant that 'the demands for privacy may increase'. ${ }^{40}$

An emphasis on the privacy of the individual was also evident in reactions to Parker Morris's inquiries into open plan house designs. Open plan arrangements were considered because the committee viewed them as an example of modern house design which might become more popular in the future. However, despite this voguish appeal, almost all respondents opposed open plan layouts on the basis of the infringement of individual privacy that would occur. The Institute of Municipal Engineers (whose members were often responsible for local authority house designs) felt that open plan designs were 'generally...unsatisfactory owing to lack of privacy [and] not adaptable to modern family life'. ${ }^{41}$ The evidence submitted on behalf of readers of the newspaper Woman's Mirror agreed that "open planning" in a small dwelling does not allow for much privacy for individual members, for homework and study, courting, entertaining guests or pursuing hobbies'. ${ }^{42}$ The reactions against open planning illustrate the preeminent importance placed upon individual privacy in housing design. Whereas domestic privacy in the nineteenth and early-twentieth centuries was understood largely in terms of separation and seclusion from 'the public sphere', by the post-war period privacy in the home was increasingly understood as personal space for each member of the family to engage in individualised leisure. ${ }^{43}$ The Society of Housing Managers argued that, rather than open planning and communal space, 'provision of adequate space for separate family pursuits [was] needed'.44

\footnotetext{
${ }^{39}$ TNA:PRO, HLG, 37/127, Evidence of City of Manchester Housing Department, 5 October 1959, 1.

${ }^{40}$ TNA:PRO, HLG, 37/127, Evidence of City of Manchester Housing Department, 5 October 1959, 1.

${ }^{41}$ TNA:PRO, HLG, 37/127, Evidence of Institute of Municipal Engineers, N.d.[c.1959], 1.

42 TNA:PRO, HLG, 37/149, Evidence from Woman's Mirror, 15 October 1959, 7.

${ }^{43}$ Mike Hepworth, 'Privacy, Security and Respectability: the Ideal Victorian Home', in Chapman \& Hockey (eds.), Ideal Homes?, 17-29. See also Leonore Davidoff \& Catherine Hall, Family Fortunes: Men and Women of the English Middle Class 1780-1850 (London, 1987) on the separate spheres.

${ }^{44}$ TNA:PRO, HLG, 37/155, Evidence of Society of Housing Managers, September 1959, 4.
} 
The tension between notions of the family as an integrated unit, or as a collection of private individuals, manifested itself in debates about the technologies of heating the home. If the home was the spiritual site of the family, the hearth was its symbolic centre. In 1950, for example, at a conference on local government house design organised by the National Women's Citizen Association, one delegate claimed that the living room fireplace was 'the soul of the British home'. ${ }^{45}$ Sociologist Dennis Chapman's 1955 survey of home life also emphasised that 'the open fire is important as the traditional centre of the life of the family group in Britain'. ${ }^{46}$ Many of Parker Morris's respondents shared this view of the hearth as the focal point of familial sociability. ${ }^{47}$ Yet in homes without central heating (which did not reach a majority of British households until 1977), gathering around the fireplace was also the only means of keeping warm. ${ }^{48}$ The Society of Medical Officers felt that 'house heating has played a major part in the ineffective utilisation of space [and that] where reliance is placed solely on the open fire a major portion of the house is thrown out of general use for about two thirds of the year'. ${ }^{49}$ The growth of the market in various types of house heaters was, according to the committee, a reflection of the demand for more individualised domestic habits. ${ }^{50}$ The open fire and the central heating system then, were tied to two competing models of what a family was, and how its members would behave in the home.

One family member who was presented as particularly in need of the extra physical and psychological space which improved heating would provide was the teenager. One of the

\footnotetext{
${ }^{45}$ Reported in 'Humanity in House Design', The Manchester Guardian, 28 October 1950, 4. On the symbolic importance of the hearth in the Victorian period see Hepworth, 'Privacy, Security and Respectability', 25-26.

${ }^{46}$ Chapman, The Home and Social Status, 43.

${ }^{47}$ TNA:PRO, HLG, 37/154, Evidence of Building Societies Association [BSA], 2 October 1959, 3; TNA:PRO, HLG, 37/144, Evidence of Federation of Registered House-Builders, N.d. [c.1959], 5; TNA:PRO, HLG, 37/127, Evidence of LHC, January 1960, 1.

${ }^{48}$ On the spread of central heating in Britain see James Obelkevich, 'Consumption', in James Obelkevich \& Peter Caterall (eds), Understanding Postwar British Society (London, 1994), 141-154, 147.

${ }^{49}$ TNA:PRO, HLG, 37/148, Evidence of SoMOH, September 1959, 4.

${ }^{50}$ MHLG, Homes, 3.
} 
committee's working papers argued that 'if the whole of the dwelling can be heated... much of the pressure for more separate spaces, intensified by homework, television and the needs of adolescents, can be met by using bedrooms for daytime activities, ${ }^{51}$ There was a remarkable degree of consensus amongst public and private sector experts that new spaces were needed within the home to accommodate the needs of teenagers, and many respondents shared the view that a young person's bedroom must be large enough to allow for study, leisure, and for the nourishment of an interior life. The Building Societies Association reported that 'adolescents appear to wish to lead a more independent life and it is desirable therefore that their bedrooms should be large enough to permit their use as bed-sitting rooms, ${ }^{52}$ The Society of Medical Officers felt that 'the adolescent needs space to carry out his hobbies, to undertake his studies, enjoy his personal treasures and to entertain his friends elsewhere than in a room shared with his parents and younger siblings. ${ }^{53}$ This space would, the Society hoped, 'help in the psychological development of the adolescent by giving him scope to develop his personal aptitudes and to express his desires and ambitions. ${ }^{54}$

The establishment of 'the teenager' as a consuming subject in her or his own right appears to have entitled young people to increased domestic space in which to develop their personality and tastes, pursue their education, enjoy and engage with their material possessions and gain a sense of self-knowledge. As with the figure of the affluent worker, the post-war teenager had important interwar precursors and was not as novel as contemporaries imagined. ${ }^{55}$ Again, the Parker Morris committee were responding to social and demographic changes which intensified rather than originated in the post-war era. Nonetheless, in the post-war decades, as

\footnotetext{
51 TNA:PRO, HLG, 37/112, 'H.S.7: Living Arrangements', PMC Working Paper, Feb 1959, 2.

52 TNA:PRO, HLG, 37/154, Evidence of BSA, 2 October 1959, 1.

53 TNA:PRO, HLG, 37/148, Evidence of SoMOH, September 1959, 4.

${ }^{54}$ TNA:PRO, HLG, 37/148, Evidence of the SoMOH, September 1959, 3.

${ }^{55}$ See Selina Todd, Young Women, Work and the Family in England, 1918-1950 (Oxford, 2005); David Fowler, The First Teenagers: The Lifestyle of Young Wage-Earners in Interwar Britain (London, 1995).
} 
Bill Osgerby and others have shown, educational reforms, rising household incomes and new employment opportunities combined to give 'British youngsters definition as a cultural entity as never before. ${ }^{56}$ The newly-coined epithet of 'teenager' itself-which entered into British popular discourse in the 1950s_captured this sense of a new social category with distinctive needs and expectations. ${ }^{57}$ At the same time as Parker Morris's investigations were underway, the market researcher Mark Abrams' 1959 study The Teenage Consumer identified a new cultural and economic actor to which the commercial domain must respond. ${ }^{58}$ Parker Morris's report was unequivocal that the needs and desires of young adults must be accommodated within the home, and that these needs were firmly tied to consuming practices and self-expression:

Through collections, hobbies and perhaps more homework; through bigger beds and the stage of clumsiness, the children will evolve into young adults, most with incomes of their own; with greater needs of privacy, a larger accumulation of possessions, often noisy ways of passing the time, and for an increasing number a real need for somewhere quiet to work at their further education..$^{59}$

Without new technologies of heating the home, Parker Morris's committee feared that individuals would not be able to enjoy the personal space and personalised leisure which had come to be seen as crucial to the satisfaction of their expressive needs:

A desire to live their own lives for an increasing part of the time they spend at home is spreading through the family as a whole...teenagers wanting to listen to records; someone else wanting to watch the television; someone going in for do-it-yourself; all these and homework too mean that the individual members of the family are more and more wanting to be free to move away from the fireside to somewhere else in the home. ${ }^{60}$

Under the influence of affluence and individualism, the family was re-imagined as a collection of unique consuming subjects, each with their own needs, habits and spaces within the home.

\footnotetext{
${ }^{56}$ Bill Osgerby, Youth in Britain since 1945 (Oxford, 1998), 17; Selina Todd \& Hilary Young, 'Baby-boomers to "Beanstalkers": Making the Modern Teenager in Post-war Britain', Cultural and Social History 9 (2012), 451-467.

${ }^{57}$ Osgerby, Youth in Britain, 34-35.

${ }^{58}$ Mark Abrams, The Teenage Consumer (London, 1959).

${ }^{59}$ MHLG, Homes, 9.

${ }^{60}$ MHLG, Homes, 2.
} 
Central heating, personal space, and individual privacy within the home were viewed as means of servicing the requirements of a society of home-centred consumers, and reflected a shift from familial to individualist models of social need. Indeed, this highly-individualist model of social democratic citizenship and welfare saw the state begin to assume responsibility for personal fulfilment and satisfaction, for needs which were emotional and expressive as well as physical. In the late-1950s context of burgeoning cultures of domestic consumption, this heightened emphasis on the material and psychological well-being of each individual was accompanied by a belief that domestic fulfilment was tied to engagement with the commercial world of hobbies, leisure and possessions.

\section{Accommodating the Consumer Housewife}

Along with the teenager, Parker Morris's papers reveal the identification of another new subject for housing policies to accommodate: the consumer-housewife. The room which received the most scrutiny from the Parker Morris committee was undoubtedly the kitchen, which was understood as both the most functionally-important room-'the centre of work and organisation in the home'-and as a critical site where a number of interconnected and farreaching social transformations were being played out ${ }^{61}$ One of the committee's first instructions was to assess the impact of 'modern household equipment' on patterns of home life, and it was in the kitchen where new technologies were felt to be transforming the work and domestic experiences of the housewife. The increasing spread of 'labour-saving devices', along with the much-commented-upon (and much overstated) assistance from reconstructed husbands, had, the report argued, begun to produce 'an easier, more varied and more enjoyable

${ }^{61}$ TNA:PRO, HLG, 37/112, 'H.S.6: Kitchens', PMC Working Paper, Feb 1959, 1. 
home life', in which the housewife 'has more free time to live a life of her own'. ${ }^{62}$ There was widespread acknowledgement from the committee and respondents that, for many housewives, this 'life of her own' entailed paid employment outside the home, but also a heightened emphasis on women's leisure and satisfaction within the home. Leeds's Housing Committee, for example, talked of women's 'psychological' need for 'a room which is purely for leisure within her own home' $^{63}$

In addition to this stress on women's lives and leisure beyond the kitchen, there was a strong sense that shifting patterns of work and domesticity were transforming the function and meaning of 'the kitchen' itself in ways which housing design had been slow to respond to. Public housing professionals, women's groups, local authorities, builders, manufacturers, medical experts, and, as far as their views were represented to the committee, householders all tended to agree that British kitchens were too small and often poorly laid out. One in three of the Woman's Mirror respondents 'had severe criticisms of the design of the kitchen'. ${ }^{64}$ A senior public housing official from the United States, Abner Silverman, told Parker Morris that kitchen design was the primary 'shortcoming of British practice', and the Building Societies Association offered the view that, 'the first priority is the larger kitchen'. ${ }^{65}$ This unanimous call for larger and better designed kitchens was based on a recognition that, for all classes of household, kitchens now needed to accommodate, in the words of the British Electrical Development Association, 'the necessary

\footnotetext{
${ }^{62}$ MHLG, Homes, 2. On the post-war myths and realities of the 'New Man' see Laura King, 'Hidden Fathers? The Significance of Fatherhood in Mid-Twentieth-Century Britain', Contemporary British History 26:1 (2012), 25-46; Ina Zweiniger-Bargielowska, 'Housewifery', in Zweiniger-Bargielowska (ed.), Women in TwentiethCentury Britain (Harlow, 2001), 149-164. On the myths of 'labour-saving devices' see Ruth Schwartz Cowan, More Work for Mother: the Ironies of Household Technology from the Open Hearth to the Microwave (London, 1983).

${ }^{63}$ TNA:PRO, HLG, 37/127, Evidence of LHC, January 1960, 14 (emphasis in original).

${ }^{64}$ TNA:PRO, HLG, 37/149, Letter from May Abbott of Woman's Mirror, N.d. [c.1959?].

${ }^{65}$ TNA:PRO, HLG, 37/138, Evidence of Abner Silverman, 6 January 1960, 1; TNA, HLG, 37/154, Evidence of BSA, 2 October 1959, 11.
} 
appliances [on which] the housewife depends for the easy and efficient running of her home ${ }^{66}$ Equally widespread was the recognition that the decline of domestic service, combined with larger demands on women's time outside the home and 'the greater informality of home life', had produced a broad-based shift in which families across classes were eating some or all of their meals in the kitchen. ${ }^{67}$ With one or two outraged exceptions, the committee and its respondents accepted that kitchens must accommodate a table suitable for family meals, and that the space had become another 'living room' in which all members of the family spent at least some of their time. $^{68}$

As well as highlighting change in the social functions of the kitchen, Parker Morris also points to a remodelling of the needs of the housewife herself which becomes clear when viewed against a longer trajectory of housing policies and campaigns. Calls for better designed and equipped kitchens had a long pre-history, and were associated in particular in the interwar period with women's groups working within and beyond the main political parties, and often in alliance with the gas and electricity industries. In the 1920s and 1930s, both Labour and the Conservatives courted newly-enfranchised female voters via housing issues, and women's groupings within the two parties effectively established housing as a key area of competence and consultation. ${ }^{69}$ Perhaps more significant were the activities of non-aligned women's voluntary groups such as the National Council of Women, the Mothers' Union, the National Federation of Women's Institutes and the National Union of Townswomen's Guilds. These groups were explicitly non-feminist, and largely represented a middle class, socially-conservative, women's interest, yet as Caitriona Beaumont has shown, they were highly effective at asserting a feminine

\footnotetext{
66 TNA:PRO, HLG, 37/158, Evidence of British Electrical Development Association, 14 October 1959, 7.

${ }^{67}$ MHLG, Homes, 2 \& 10. On the decline of domestic service see Judy Giles, 'Help for Housewives: Domestic Service and the Reconstruction of Domesticity in Britain, 1940-50', Women's History Review 10:2 (2001), 299324.

${ }^{68}$ MHLG, Homes, 10; TNA:PRO, HLG, 37/138, Evidence of HCT, N.d. [1959?], 3.

${ }^{69}$ See Martin Pugh, Women and the Women's Movement in Britain (Basingstoke, 2000), 124-139.
} 
political voice centred on women's rights and expectations as housewives and mothers. ${ }^{70}$ Their interwar campaigns for recognition of the housewife's political rights as a citizen overlapped and intersected with burgeoning commercial appeals to the female consumer in her home as well as with 'the scientific reform of domestic life' pursued by nutritionists and devotees of household management..$^{71}$

As early as the 1920s then, the interests of power companies, women's magazines, appliance manufacturers, advocates of domestic science and the wider women's movement had coalesced around demands for improved kitchens, often with reference to American interior design and scientific management principles. Housecraft manuals, magazines, show homes, newspapers, and design spectacles like the Daily Mails Ideal Home Exhibition all served to display and promote the modern, efficient and convenient kitchen to those who could afford it. ${ }^{72}$ For their part, civic-minded women's groups tended to see in these endeavours a path towards a more active and fulfilling form of citizenship for the housewife, who, once the daily drudgery of domestic work was relieved, would be able to occupy a more prominent and rewarding place in public and political life. For Beaumont, the 1944 Dudley Report into local authority housing standards (Parker Morris's predecessor) represented 'a triumph for women's organisations [and] a vindication of the years spent campaigning on housing. ${ }^{73}$ Dudley's sensible prescriptions for kitchens equipped with sinks, draining boards, work surfaces, cookers and ventilated larders reflected women's groups' effective advocacy on behalf of the citizen-housewife. ${ }^{74}$

\footnotetext{
${ }^{70}$ Caitriona Beaumont, Housewives and Citizens: Domesticity and the Women's Movement in England, 1928-64 (Manchester, 2014).

${ }^{71}$ James Vernon, Hunger: A Modern History (London, 2007), 216.

72 Vernon, Hunger, 216-223.

${ }^{73}$ Beaumont, Housewives and Citizens, 174.

${ }^{74}$ Nicholas Bullock, Building the Post-War World: Modern Architecture and Reconstruction in Britain (London, 2002), 155-158.
} 
In the 1940s, the Dudley kitchen sat within the wider framework of the post-war Beveridgean welfare state, with its pronatalist conception of the rights and duties of the housewife as valued citizen of the social democratic state. ${ }^{75}$ By the late-1950s, when the Parker Morris committee looked again at the shape of the British kitchen and the needs of the British housewife, these earlier models of womanhood, domesticity and citizenship retained much of their force, and were often presented by the very same women's organisations that were influential in the Dudley era and interwar years. Much of the language of Parker Morris continued to invoke the state's responsibility to provide the citizen-housewife with the space and equipment with which to carry out her work effectively. The report argued for example that, 'a woman needs all the help she can get from her kitchen', and that 'only a small number of kitchens in local authority houses are reaching the really high standard required'. ${ }^{76}$ In private housing it was felt that although 'there is much more attention paid to appearance and cheerfulness there is lacking still the thought and organisation that can make a kitchen an efficient and satisfactory place to work in'. ${ }^{77}$ The field of scientific management and domestic engineering also retained its intellectual and political authority in the Parker Morris era, and continued to be most powerfully marshalled by women's groups and public health professionals who called for meticulous planning to ensure the housewife's rights to safety and efficiency in her workplace were met. This was the model of female domestic needs which was ultimately endorsed and enshrined in Parker Morris's recommendations, which deferred to the greater knowledge and experience of the Women's Group on Public Welfare's Council of Scientific Management in the Home (COSMITH). Parker Morris's prescriptions for kitchen layouts were based almost entirely on the ideas and arguments of COSMITH, which was able to furnish the

\footnotetext{
${ }^{75}$ On Beveridge and post-war pronatalism see Denise Riley, War in the Nursery: Theories of the Child and Mother (London, 1983); Penny Summerfield, 'Women in Britain since 1945: Companionate Marriage and the Double Burden', in Obelkevich \& Catterall (eds.), Understanding Post-war British Society, 58-72.

${ }^{76}$ MHLG, Homes, 19.

${ }^{77}$ MHLG, Homes, 19.
} 
committee with published reports of its scientific research into domestic principles and practice. $^{78}$ Such ideas were also deeply embedded within the wider public sector, with many local authorities, health and housing professionals adopting the language of prescriptive scientific design. The Housing Centre Trust, for example, considered that 'good kitchen planning is a matter of the intelligent and careful application of known principles', and Manchester's Housing Department felt that 'the sequence of equipment should be the subject of the most careful planning designed to ease the housewife's work and to minimise the danger of accidents' ${ }^{79}$

Within the Parker Morris papers however, there is evidence that an alternative, consumerist model of the kitchen and the housewife was gaining intellectual ground. A range of organisations and experts claiming to speak on behalf of the consumer-housewife asserted their right to define the form and function of the British kitchen, and presented a competing picture of women's needs. It was one in which overly-prescriptive planning would inhibit the housewife's ability to use her kitchen as a site of leisure and self-expression through personalising her home and exercising choice over domestic consumer goods. Manufacturers, house-builders and trade bodies stressed that the consumer-housewife must have the freedom to engage creatively with the world of goods, to endorse her favoured brands, and perhaps remodel this space at a later date. The British Refrigeration Association, for example, strongly opposed prescriptive designs and 'recommend[ed] that householders should have as much freedom as possible in choosing their kitchen equipment [because] tastes differ and so do the designs of different brands' ${ }^{80}$ The Furniture Development Council argued against fixed fittings in the kitchen (which its members could not sell) because 'various types of mobile kitchen fittings are already on the market [which] gives opportunities for individual expression'. ${ }^{81}$ The Women's

\footnotetext{
${ }^{78}$ Included in TNA:PRO, HLG, 37/167, Evidence of COSMITH.

79 TNA:PRO, HLG, 37/127, Evidence of City of Manchester Housing Department, 5 October 1959, 4.

${ }^{80}$ TNA:PRO, HLG, 37/134, Evidence of British Refrigeration Association [BRA], 30 June 1959, 6.

${ }^{81}$ TNA:PRO, HLG, 37/187, Evidence of the Furniture Development Council, 30 June 1960, 3.
} 
Advisory Council on Solid Fuel suggested that, whilst a 'properly thought out sequence of equipment will eliminate unnecessary movement', there was nonetheless 'a tendency to overplan the kitchen' and 'space should be left to provide scope for individual taste and initiative'. ${ }^{82}$ In general, the Council felt that much in kitchen design was 'a matter of individual choice'. ${ }^{83}$ The Federation of Registered House-Builders felt it 'necessary to stress that nothing should be done to invalidate the freedom of choice of individuals' when it came to furnishing and equipping the kitchen. ${ }^{84}$

These consumerist imperatives of individual choice and self-expression were standard fare for the commercial agents who presented them most forcefully, and many were clearly also attempting to steer Parker Morris away from proposing new regulations which might prove commercially-damaging. Yet there is plenty of evidence that within the public sector consumerist models of the housewife's needs and expectations were gaining acceptance. The language of individual choice entered into the deliberations of many public sector and professional bodies. The Society of Medical Officers, for example, felt that, aside from installing cupboards and a kitchen sink, 'otherwise only space should be provided to enable the housewife to make her own choice' ${ }^{85}$ A comparison with the same professional body's submission to the Dudley committee is particularly instructive. In 1944 the Society called for 'formal instruction' in 'housewifery and mothercraft', and advocated 'careful planning...particularly of the kitchen and scullery' which was described simply as the 'workroom for the housewife'. ${ }^{86}$ By 1959 , local authority figures such as Paddington's Director of Housing and Borough Architect suggested that working practices in the kitchen were 'a matter of the housewife's personal preference', and that decisions on kitchen

\footnotetext{
${ }^{82}$ TNA:PRO, HLG, 37/150, Evidence of WACSF, September 1959, 4.

83 TNA:PRO, HLG, 37/150, Evidence of WACSF, September 1959, 4.

${ }^{84}$ TNA:PRO, HLG, 37/144, Evidence of Federation of Registered House-Builders, N.d. [c.1959], 9.

${ }^{85}$ TNA:PRO, HLG, 37/148, Evidence of SoMOH, September 1959, 8.

${ }^{86}$ TNA:PRO, HLG, 37/64, Society of Medical Officers of Health, 'Design of Dwellings', N.d.[1942?], 2 \& 5.
} 
appliances 'are matters of individual choice, ${ }^{87}$ There was also a growing recognition that an adequate public standard of domestic comfort must now accommodate the housewife's psychological need for self-expression and fulfilment via the world of domestic consumption. Plymouth's City Architect highlighted 'the prestige element of possession of automatic dishwashers, outsize refrigerators', and went on to argue that:

The planning and sequence of rooms and spaces around and within the kitchen are undergoing radical changes...To ignore sociological facts of "status" and "display" and the emotional aspects of furnishing will always leave the broad public stone cold. ${ }^{88}$

Once housing professionals had begun to acknowledge the importance of 'the emotional aspects of furnishing', and, by extension, the crucial role of the private sector in meeting those needs, the representatives of consumer industries necessarily gained a greater voice in public policy-making. Parker Morris's enquiries across all areas of housing design are remarkable for their level of engagement with developments in the private sector and for the extent of consultation with commercial interests. In the field of kitchen planning, it became clear that publicly-mandated standards must now be responsive to trends in the consumer goods market, and various trade and industry bodies were invited to instruct the committee on the designs and dimensions of fridges, cupboards and ovens. Organisations like the English Joinery Manufacturers Association, British Refrigeration Association, National Association of Retail Furnishers, and the British Electrical and Allied Manufacturers Association offered detailed prescriptions of the domestic shapes and sizes which were necessary to accommodate the essential needs of the consumer-housewife, submitting tables of measurements, product advertisements, drawings and suggested plans to the committee. ${ }^{89}$

This was a call for a public governance shaped by market logics and commercial imperatives, one which would facilitate and encourage each individual citizens' engagement with

\footnotetext{
87 TNA:PRO, HLG, 37/161, W.H. Beesley. 'Replies to Questionnaire', September 1959, 4.

${ }^{88}$ TNA:PRO, HLG, 37/127, H.J.W. Stirling, 'Replies to Questionnaire', August 1959, 4.

${ }^{89}$ See TNA:PRO, HLG, 37/162 \& TNA:PRO, HLG, 37/132.
} 
the world of consumer goods. The Association of Retail Furnishers argued, for example, that all kitchens should be planned in six foot gradations because these were the dimensions in which linoleum was manufactured..$^{90}$ Others, like the Refrigeration Association and the Association of Electrical Housecraft Advisors, argued that not only did the modern kitchen require space for 'a reasonable selection of electrical appliances', but that space should also be factored in to accommodate any 'new appliances that are likely to be introduced to the market in the future'. ${ }^{91}$ Norman Wates, a member of the Parker Morris committee and director of a large building and civil engineering firm, also stressed 'the need for space [in kitchens] to take care of machines not yet produced or even invented'. ${ }^{92}$ In a particularly productivist take on domestic needs Wates also declared himself 'tremendously impressed with the National necessity for providing space within the homes which will take the goods which our factories are going to produce over the next $20 / 25$ years. ${ }^{93}$ The entreaty to anticipate future trends in consumer goods was written in to Parker Morris's final report, which called on architects to be responsive to the dynamism of the consumer market in which 'machines at present requiring attendance will become automatic; some machines now rarely found... will become increasingly common; and appliances not yet invented will make their appearance'. ${ }^{94}$

Parker Morris then, represents a moment in which the logics and imperatives of post-war consumerism began to have identifiable and far-reaching impacts upon models of citizenship, governance and welfare. In the case of the housewife, this was manifested in a reconceptualization of women's needs in the home, with a greater emphasis on leisure and satisfaction, as well as on individual choice as opposed to prescriptive planning. Crucially, this shift in publicly-defined models of female domesticity entailed a growing recognition of the

\footnotetext{
${ }^{90}$ TNA:PRO, HLG, 37/132, Evidence of Retail Furnishers, May 1959, 2.

${ }^{91}$ TNA:PRO, HLG, 37/134, Evidence of BRA, 30 June 1959, 5.

92 TNA:PRO, HLG, 37/203, Letter from Norman Wates to PMC Secretary, 9 February 1961.

${ }^{93}$ TNA:PRO, HLG, 37/203, Letter from Norman Wates to PMC Secretary, 9 February 1961.

${ }^{94}$ MHLG, Homes, 21.
} 
psychological and expressive comforts which were understood to accrue from women's participation in commercial cultures of domestic consumption, and a corresponding turn to the commercial sphere for guidance and expertise. Although Parker Morris's participants tended to assume that these changes in female domestic life were a product of the 'social and economic revolution' of post-war affluence, in fact they formed part of a longer trajectory of change in female domestic experience stretching back to at least the interwar period. A number of works in recent years have drawn attention to the interwar 'reconstruction of womanhood' brought about by the conjoined influence of shrinking family sizes and rising real wages, extensive new housebuilding and suburbanisation, a consumer goods boom, and new media and commercial constructions of 'modern femininity'. ${ }^{5}$ These interwar trends towards improved housing conditions, greater domestic comfort, and an enhanced engagement with consumer culture for women were strongly structured by wealth, class and locality, and this remained the case in the post-war era. ${ }^{96}$ Nonetheless, in the post-war context of full employment, rising disposable incomes, two income households, and extended welfare provisions, many more women than ever before could expect to enjoy the benefits of a more comfortable, more affluent, domestic existence. The post-war extension and intensification of women's engagement with consumer culture can be crudely read from the dramatic increases in sales of women's magazines, with the leading $W$ oman going from 750,000 in 1939, to one million in 1940, and 3.5 million by the time of Parker Morris in the late-1950s. ${ }^{97}$ The sophisticated appeals of post-war market researchers to 'the mass-market housewife' via the new medium of the TV advert also stand as evidence for a deep and broad-based engagement of women with the commercial domain. ${ }^{98}$ The languages of domestic satisfaction, leisure, self-expression, and consumer choice which entered into Parker

\footnotetext{
${ }^{95}$ For discussion see Adrian Bingham, “"An Era of Domesticity?” Histories of Women and Gender in Interwar Britain', Cultural and Social History 1:2 (2004), 225-233.

${ }^{96}$ Langhamer, 'The Meanings of Home'.

${ }^{97}$ Figures in Pugh, Women and the Women's Movement, 209-210.

${ }^{98}$ See Sean Nixon, Hard Sell: Advertising, Affluence and Transatlantic Relations, c. 1951-69 (Manchester, 2013), esp. 127-135.
} 
Morris's public deliberations about women's rights and expectations echoed these developments in the commercial sphere, as the selection of mid-1950s adverts in figures 1-4 demonstrate.

Given her interwar forebears, what was significant about Parker Morris's engagement with the consumer-housewife was not so much the identification of a 'new' social actor, but the sense that standards of domestic comfort which had previously been available only to some could conceivably now be demanded by all citizens. The ability to purchase an 'exciting new cooker', or the kitchen surfaces which would 'make a dream home complete', came to be seen by the late-1950s not as a 'private' luxury, but as part of publicly-defined norms of domesticity and womanhood. ${ }^{99}$ As with the demands and desires of the teenager, Parker Morris's vision of the housewife's needs demonstrated a high level of responsiveness to consumer- and market-driven social change, as the committee engaged directly with the growing importance of domestic consumption in women's lives, and a new, consumerist understanding of the female in her home began to supplant earlier models based on the working rights of the citizen-housewife. This consumerist remodelling of the female domestic subject encouraged public officials to recognise the limits of their own capacities to manage women's lives, and introduced new commercial logics and agents into the structures of public governance.

\footnotetext{
${ }^{99}$ Quoted from adverts considered by PMC in TNA:PRO, HLG, 37/206.
} 


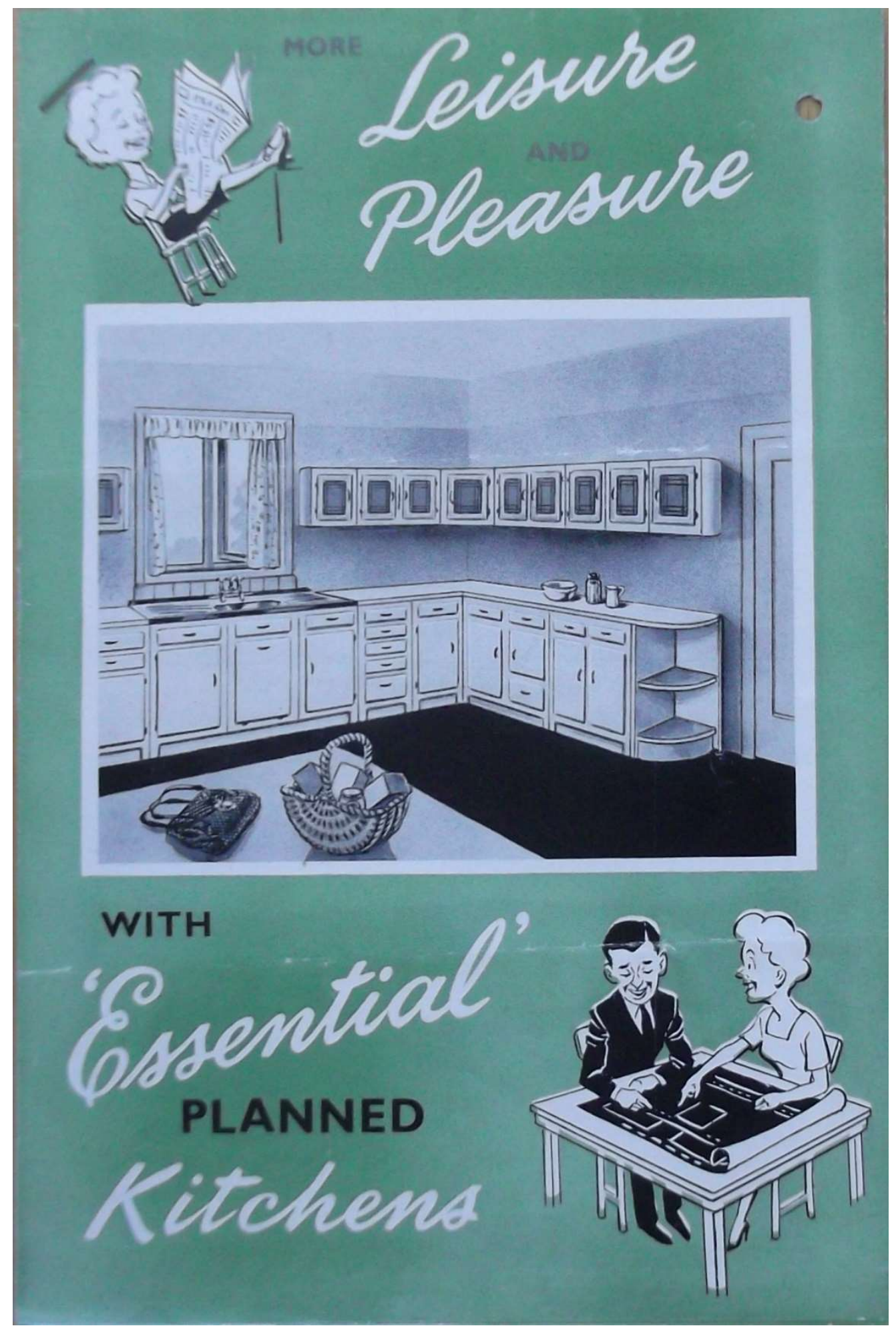

Figure 1: Advertisement for 'Essential Planned Kitchens', stressing the offer of 'more leisure and pleasure' for the housewife. The ad is from the mid-1950s and appears in the Building Research Station's collection on COSMITH's show kitchen at the 1955 Ideal Home Exhibition. TNA:PRO, Department of Scientific and Industrial Research [DSIR], 4/2766. 


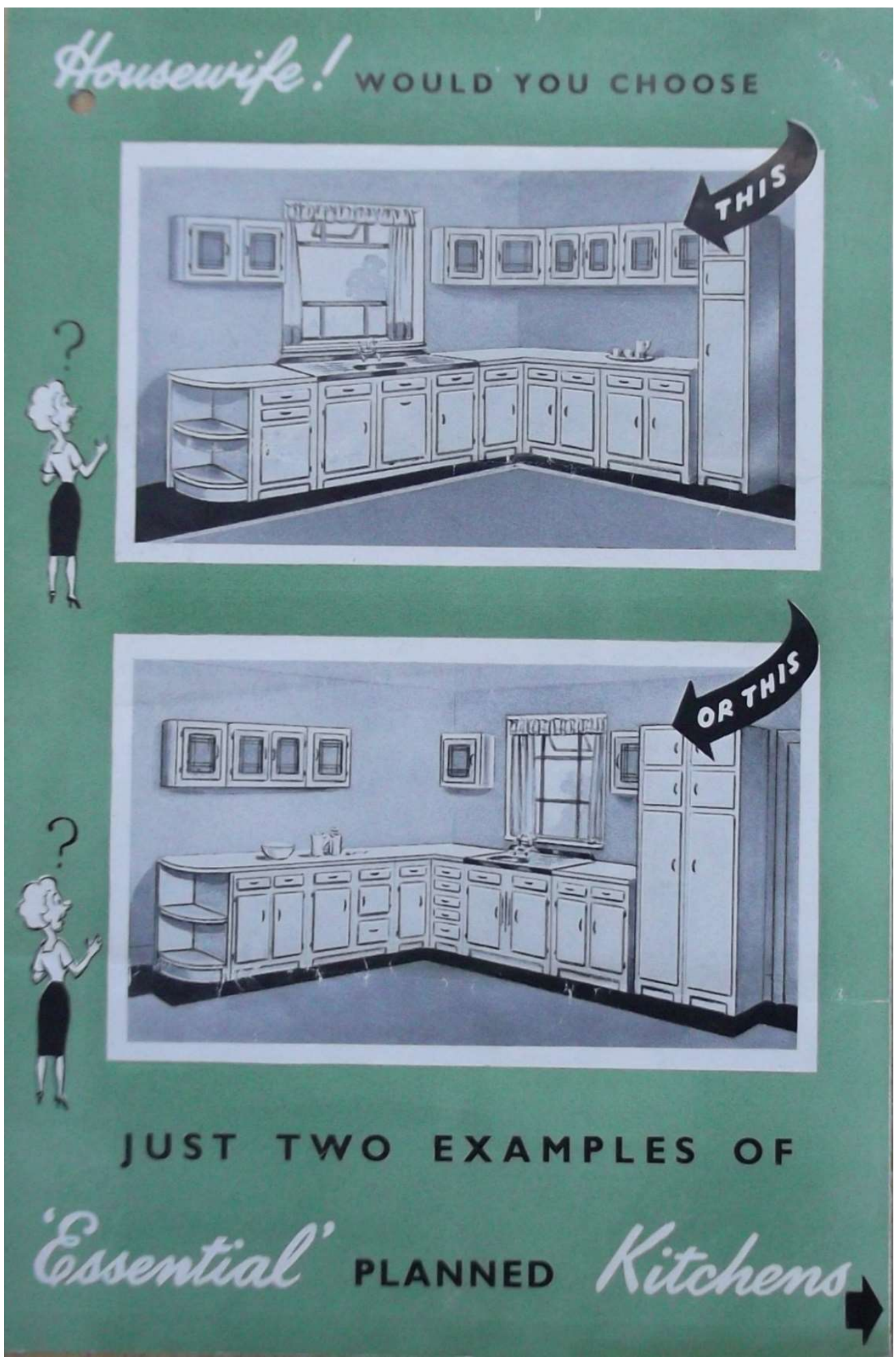

Figure 2: Advertisement for 'Essential Planned Kitchens' (mid-1950s), with an explicit appeal to the housewife to make her own choice. TNA:PRO, DSIR, 4/2766. 


\section{Make your home a 'SHOWHOUSE' by furnishing at BROWNS}

20 HAYMARKET

Browns is the friendly, homely store with the modern outlook and a reputation for personal service. In our Haymarket showrooms you will find the finest selection anywhere, of high-quality furniture. bedding, carpets, electrical goods-all by leading makers, including G-Plan, Beautility. Homeworthy, Greaves \& Thomas, Slumberland, Vono, etc Here too, you will always find an excellent selection of the most famous brands of Television, Radios and Record Players. Everything is anilable on easy terms, which may be spread over 2 years wich a minimum deposit, or paid for in 38 weeks without deposic.

It's so much more satistying to furnish at BROWNS

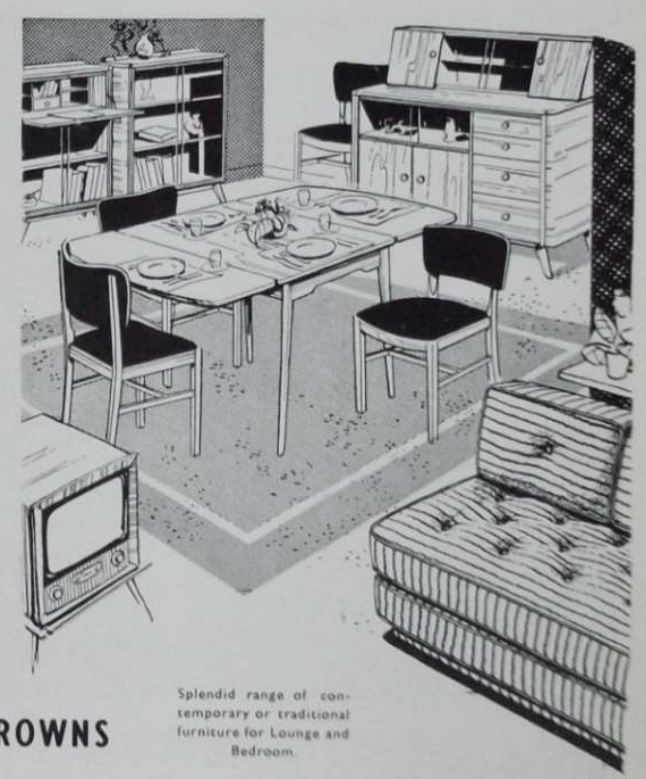

Figure 3: Advertisement for Browns furnishers, taken from a house marketing brochure within the Parker Morris papers. The company offers a 'modern outlook', and 'excellent selection of the most famous brands', in order to make the home 'more satisfying'. TNA:PRO, HLG, 37/206, 'Calverley Presents the Ideal Home', promotional brochure, N.d. [c.1959].

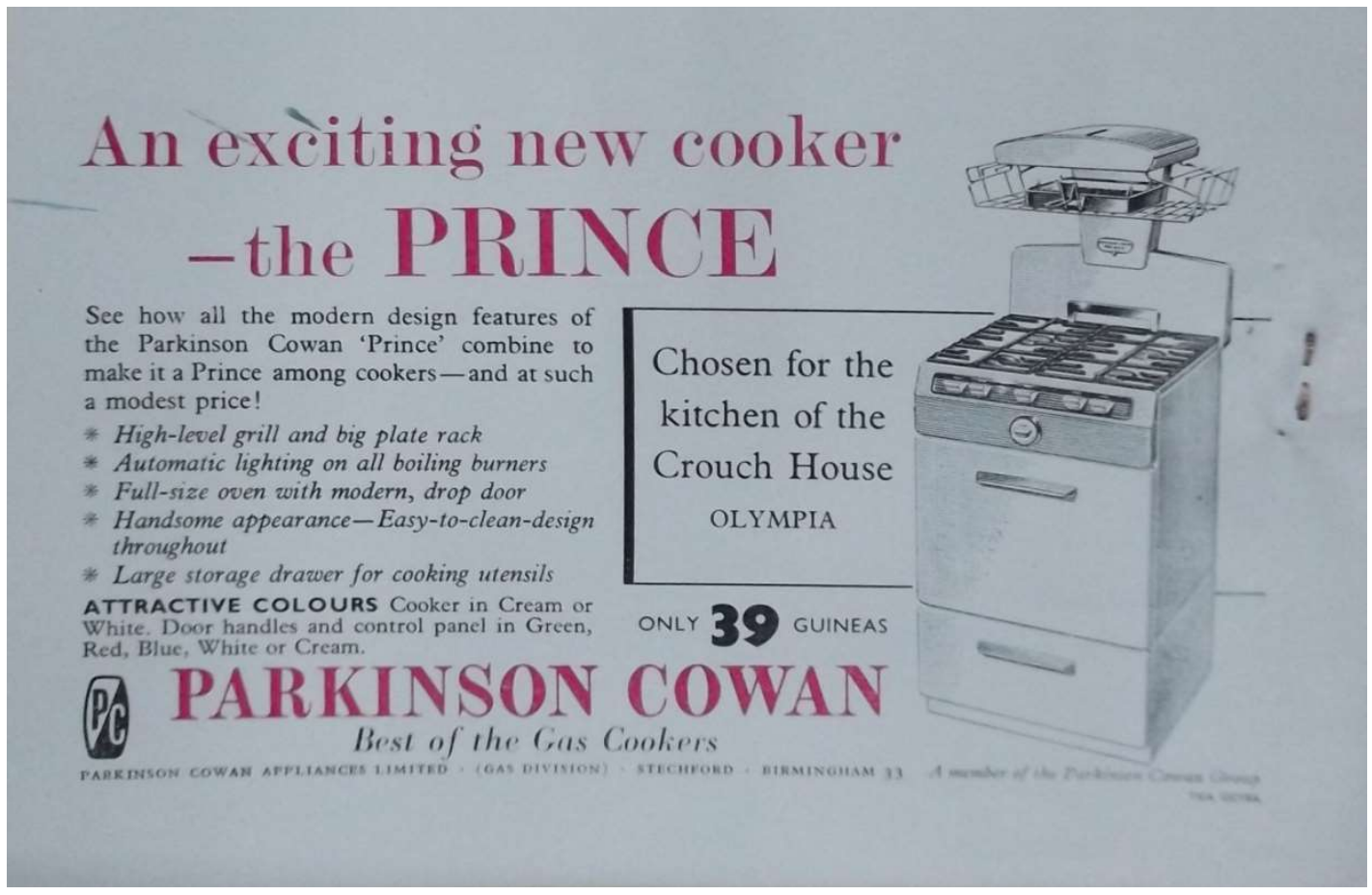

Figure 4: Advertisement for an 'exciting new cooker', available in a choice of 'attractive colours', and on display at the Ideal Home Exhibition at Olympia. Included in the Parker Morris papers, TNA:PRO, HLG, 37/206, N.d. [c.1959?]. 


\section{The State, the Market, and the Consuming Citizen}

Parker Morris's deep and sustained engagement with the importance of consumption in individuals' lives, and the incorporation of consumer satisfaction into models of citizens' rights and social democratic selfhood, reflected the committee's faith that the material and psychological comforts of affluence could and should be extended to each individual citizen. Yet the attempt to integrate these consumerist and highly-individualist logics into systems of collective welfare provision was fraught with contradictions. By promoting individual consumer choice as a guarantee of healthy subjectivity, the committee implicitly challenged the very bases of universal forms of social provision, centred on standardised models of need determined and administered by politicians and technocrats. This had clear consequences for governance and policy-making, not least in terms of the appropriate and authoritative forms of social knowledge on which policy could be based. Consumerist imperatives of individual choice undermined traditional sources of social expertise within the public sector and medical professions, whose claims to knowledge and authority over the lives of ordinary Britons were weakened. ${ }^{100}$ As has been seen, Parker Morris's consumerist logics enhanced the political and intellectual authority of commercial agents, who gained an amplified voice in public policy-making through their more sophisticated claims to knowledge of consumer desire. An emphasis on the individual choices of each citizen also lent itself towards new forms of direct consultation, and here again the crossfertilisation with developments in the commercial sphere is striking. The Federation of Registered House Builders told Parker Morris that it was essential that 'much more notice was taken of consumer demand' and this view was taken seriously by the committee. ${ }^{101}$ An early draft of the committee's terms of reference raised the 'possibility of ascertaining on a scientific basis

\footnotetext{
${ }^{100}$ For discussion see Mort, 'The Commercial Domain: Advertising and the Cultural Management of Demand', in Peter Jackson, Michelle Lowe, Daniel Miller \& Frank Mort (eds), Commercial Cultures: Economies, Practices, Spaces (Oxford, 2000), 35-53.

101 TNA:PRO, HLG, 37/198, Oral Evidence of Federation of Registered House Builders, 3 March 1960, 1.
} 
the views of the consumer...through a social survey'. ${ }^{102}$ Although this never materialised, the committee's insistence on personally visiting over 600 homes represented a direct survey of sorts, undertaken because they 'were most anxious to ensure that we became familiar with the diverse outlooks and problems of householders'. ${ }^{103}$

By engaging in direct consultation with the 'consumers' of housing, the committee were moving in tandem with the post-war flourishing of market research. By the late-1950s, Mass Observation had moved into commercial market research and was conducting social surveys to ascertain householders' views on a whole range of consumer products. ${ }^{104}$ At the same time, organisations like the British Market Research Bureau and the Tavistock Institute of Human Relations were developing sophisticated techniques for producing and codifying new forms of consumer knowledge for both public and private sector clients, and Mark Abrams, whose influence has been noted, was a key proselytiser for the 'social' uses of market research. ${ }^{105}$ Although this model of direct consultation with the citizen-consumer was somewhat hesitantly embraced in the Parker Morris moment, it rapidly became central to the Ministry of Housing's policy-making. John Burnett notes that between 1961 and 1975, 4,000 housewives in seventy housing schemes 'were interviewed to discover how they reacted to their dwellings and to the estates they lived in'. ${ }^{106}$ By 1970, just nine years after Parker Morris reported, two important housing studies produced for the Ministry were based squarely upon direct consultation with

102 TNA:PRO, HLG, 37/112, 'Draft: Sub-Committee on Housing Standards', January 1959, 3.

${ }^{103}$ MHLG, Homes, iv.

${ }^{104}$ Many available within University of Sussex Library, SxMOA1/2/78, TC78 Commodities 1941-64.

${ }^{105}$ See Nixon, Hard Sell, 71-74; Peter Miller \& Nikolas Rose, 'Mobilizing the Consumer: Assembling the Subject of Consumption', Theory Culture Society 14:1 (1997), 1-36; Stefan Schwarzkopf, 'A Radical Past? The Politics of Market Research in Britain, 1900-1950', in Kerstin Brückweh (ed.), The Voice of the Citizen Consumer: A History of Market Research, Consumer Movements, and the Political Public Sphere (Oxford, 2011), 29-50.

${ }^{106}$ Burnett, Social History of Housing, 310. 
housewives, using what were by then well-established social survey techniques of questionnaires, interviews, statistical sampling and tabulation. ${ }^{107}$

As well as pointing towards new forms of direct consultation with the recipients of housing policy, the consumerist logics of choice and market demand contained within Parker Morris challenged social democratic models of welfare in more fundamental ways. By tying citizens' fulfilment to the exercise of consumer choice over the space of the home, the committee further cemented the privileged status of private home-ownership as an inherently superior form of tenure, and simultaneously marked out social housing as a poor substitute. The committee's work was undertaken in a moment in the twentieth-century trajectory of housing provision in which owner-occupation was established statistically, culturally, and politically as the preferred mode of tenure. ${ }^{108}$ After the hiatus of the Second World War and six years of Labour government, the political-cultural project of extending home-ownership resumed with force in the 1950s, powerfully orchestrated by the Conservative government, national news media, volume house-builders, and building societies. ${ }^{109}$ Under Macmillan, the government's pursuit of the property-owning democracy was unrelenting, provoking complaints from the Treasury and some in his own party about the extent of state subsidies for owner-occupiers and mortgage lenders. ${ }^{110}$ In December 1959, Brooke himself as Housing Minister ceremonially opened 'the millionth' private enterprise house built since the war, at Blackheath, London, a piece of political theatre which further emphasised the favoured status of owner-occupation two decades before

\footnotetext{
${ }^{107}$ MHLG, Living in a Slum: a Study of St. Mary's Oldham (London, 1970); MHLG, Families Living at High Density: a Study of Estates in Leeds, Liverpool and London (London, 1970).

${ }^{108}$ See Peter Saunders, A Nation of Home Owners (London, 1990).

${ }^{109}$ On the trajectory of home-ownership in the interwar period see Peter Scott, 'Marketing Mass Home Ownership and the Creation of the Modern Working-Class Consumer in Inter-War Britain', Business History 50:1 (2008), 4-25.

${ }^{110}$ See TNA:PRO, HLG, 117/142, Treasury note, 11 September 1958 \& Cabinet Memo, 'Home Ownership', September 1958.
} 
Margaret Thatcher's pro-ownership agenda. ${ }^{111}$ The electoral popularity of ownership forced Labour into acquiescence: Gaitskell made tentative noises in support of ownership as early as 1958, and in 1965 the party's housing white paper recognised owner-occupation as the 'normal' tenure and proposed further expansion of the system of mortgage credit. ${ }^{112}$

Pro-ownership policies intersected with an ongoing commercial and cultural project centred on cultivating and monetising individuals' relationship with their home. Many national newspapers were vigorously pro-ownership, and presented home-ownership as simultaneously a buttress of democratic values, and crucial for individual fulfilment. The Daily Express, for example, welcomed a 1954 government scheme to underwrite a further expansion of mortgage lending by arguing that 'democracy has no surer foundation than a people with its own stakes in the land'. ${ }^{113}$ For the individual citizen, the Express suggested, such 'help to buy' meant that 'now their dreams too advance closer towards fulfilment', and responded to 'a hunger in every man's heart to own a home of his own'. ${ }^{114}$ Newspapers, advertisers, and builders stressed that the exercise of consumer choice over the house itself and the design and fittings within it was central to its function as a means of personal fulfilment. House-builders' brochures offered a range of house types to choose from, with names intended to suggest prestige such as 'the Lincoln', 'the Balmoral', or 'the Renown'. ${ }^{115}$ Different house designs and layouts were offered 'to appeal to the contemporary or traditionally minded purchaser' and 'to suit individual requirements',

${ }^{111}$ Diana Rowntree, 'Making an Honest Woman of the Modern House', The Guardian, 8 December 1959, 7. See also Aled Davies, "'Right to Buy": The Development of a Conservative Housing Policy, 1945-1980', Contemporary British History 27:4 (2013), 421-444.

112 'Mr Gaitskell Would Encourage Home Ownership', The Guardian, 3 February 1958, 9. On Labour's policies in the 1960s see Burnett, Social History of Housing, 287.

113 TNA:PRO, HLG, 117/140, 'More than 4,000,000 sale every day’, Daily Express, 16 March 1954.

114 TNA:PRO HLG, 117/140, 'More than 4,000,000 sale every day', Daily Express, 16 March 1954.

115 TNA:PRO, HLG, 37/206, 'Invest in a Berg Luxury Home', house-builders pamphlet, N.d. [c.1959]; and 'The Renown', advertisement, Crouch Builders, N.d. [c.1959]. 
encouraging buyers to identify themselves as a particular type of consumer. ${ }^{116}$ Builders also offered the option of choosing from a whole range of possible extra fittings and features such as oak thresholds, French doors and Formica kitchen surfaces. ${ }^{117}$ Through deliberating over and choosing their own desired house type, room layout, design features and modifications, buyers were encouraged to view their new home as a highly personalised expression of their own needs, character and desires.

Parker Morris's engagement with the burgeoning sphere of owner-occupation is evident not just in its emphasis on consumer choice and market logics, but in the extent of consultation with building societies and house-builders, the presence of volume house-builders on the committee, the many visits undertaken to owner-occupied homes, and the substantial amount of house brochures, adverts, and mortgage guides contained within the committee's papers. The committee's fourth meeting took place not in the Ministry's committee rooms, but at the Daily Mails Ideal Home Exhibition at Olympia, and, despite some efforts to avoid this when appointing members, every member of the committee lived their own lives in an owner-occupied home. ${ }^{118}$ The views which the committee formed about ideal types of housing and the needs of the citizen in their home were necessarily shaped by this socio-political context in which homeownership was being powerfully promoted by cultural and political elites, and where marketised consumption of the house itself was constructed as central to personal happiness and fulfilment. By embracing the idea that individuals' satisfaction with their home rested on commercial systems of market choice and consumerist self-expression, the committee implicitly endorsed the notion that collectively-provided social housing could never be an equally-acceptable alternative to the owner-occupied, commercially-consumed, private home. Indeed, Parker Morris's consumerist models of the home and the citizen, although intended to raise standards in social

\footnotetext{
116 TNA:PRO, HLG, 37/206, 'Bants Lane', pamphlet for Wilson builders, 1959.

117 TNAPRO, HLG, 37/206, 'Calverley Presents the Ideal Home', promotional brochure, N.d. [c.1959].

${ }^{118}$ See discussion of appointments in TNA:PRO, HLG, 37/111.
} 
housing, served to problematise the council home in new ways. Housing officials now recast many of their anxieties about tenants and mass housing in terms of potential constraints upon domestic consumption and self-expression. The Society of Medical Officers raised concerns about blocks of flats in particular, where:

The external decorations are not usually under the control of the occupants, they are generally quite uniform and the only variation is the curtains. There is thus a tendency to know nothing of the personality of one's neighbours except those things which cause irritation, such as excessive noise, bad behaviour of children etc. ${ }^{119}$

Here then, constraints on tenants' ability to decorate their home, and to engage in material displays of personality, were imagined as a potential threat to neighbourly relations. The Society similarly worried about tenants housed without private gardens, because gardens were seen as important means to 'express the personality of the occupants'. ${ }^{120}$

The council tenant occupied a particularly ambiguous position in Parker Morris's consumerist domestic schema, and these uncertainties indicate some of the lines of social difference and exclusion which were exposed through the attempt to unite social democratic citizenship with consumerist individualism. While some respondents agonised about tenants' ability to fully express themselves in the constrained environment of social housing, others baulked at the idea that tenants should enjoy the full domestic comforts of affluence. The National Federation of Property Owners criticised Parker Morris's 'idealistic' approach, and argued that 'there is no call for improvement in the present standard of local authority housing which should be confined to providing basic living accommodation'. ${ }^{121}$ The Federation was angered by the prospect that 'the local authority tenant enjoys greater amenities' than those living in privately-owned housing. ${ }^{122}$ Such views were relatively isolated, although they were voiced here by extremely well-connected individuals. More common was a conflict between Parker

\footnotetext{
119 TNA:PRO, HLG, 37/148, Evidence of SoMOH, September 1959, 12.

${ }^{120}$ TNA:PRO, HLG, 37/148, Evidence of SoMOH, September 1959, 12.

${ }^{121}$ TNA:PRO, HLG, 37/146, Evidence of NFPO, September 1959, 1.

122 TNA:PRO, HLG, 37/146, Evidence of NFPO, September 1959, 1.
} 
Morris's model of the free consuming citizen and the long-standing paternalist and moralising impulses which characterised social housing provision. ${ }^{123}$ In the post-war context of elite anxiety about the corrupting effects of affluence, advertising, and 'Americanisation' on the masses, such paternalism manifested itself in housing officials' attempts to protect their charges from the excesses of consumer culture.

The television was an emblematic technology of affluence and home-centredness which provoked unease from elites on precisely these grounds. ${ }^{124}$ Rates of ownership shot up dramatically in the short period in which Parker Morris worked, expanding from one in three households in 1955 , to three quarters of households by $1960 .{ }^{125}$ Although some public housing officials were relaxed about the impact of television, others were deeply concerned about the potential impacts on tenants' psyches and social outlook, and the television was perceived by some as a dangerous presence in the tenant's home and a threat to family life. Manchester's Housing Department were not alone in complaining that 'television and radio have largely destroyed privacy', and argued that a second living room was now needed to escape this intrusion. ${ }^{126}$ The paternalistic fears of the city's housing department are indicated in a 1956 speech by its chief official, in which he said 'it should be emphasised over and over again that family life can only hope to survive in these distracting times when the dwelling accommodation available is as near perfect for this purpose as can possibly be provided ${ }^{127}$ One influential member of the Parker Morris committee, pioneering modernist and Sheffield's City Architect

\footnotetext{
${ }^{123}$ On paternalism and discipline see Ravetz, Council Housing and Culture, 4.

${ }^{124}$ Lawrence Black, “'Sheep May Safely Gaze”: Socialists, Television and the People in Britain, 1949-64', in Black (ed.), Consensus or Coercion? The State, The People and Social Cohesion in Post-war Britain (Cheltenham, 2001), 28-48.

${ }^{125}$ Obelkevich, 'Consumption', 146.

${ }^{126}$ TNA:PRO, HLG, 37/127, Evidence of City of Manchester Housing Department, 5 October 1959, 2; TNA, HLG, 37/151, Evidence of the Institute for Housing, 30 September 1959, 2; TNA, HLG, 37/127, Evidence of the Institute of Municipal Engineers, N.d.[c.1959], 1.

${ }^{127}$ Speech reported in Rowland Nicholas, 'Presidential Address', Journal of the Royal Society of Public Health (1956), 344-347, 345.
} 
Lewis Womersley, suggested that 'we can easily imagine [television] destroying family life' and extolled the virtues of 'Music, Arts, Opera, Drama, Literature and Nature Study' instead. ${ }^{128}$

Other public sector actors expressed anxieties about tenants' ability to engage appropriately with commercialism, and depicted a figure whose relationship to new modes of domestic consumption required careful management. The Development Corporation of Aycliffe New Town told Parker Morris that:

Authorities should do more to show people how to furnish and use their new dwellings; the Corporation had provided a show-house at an early stage in the development of the New Town and another more recently to demonstrate the use of a particular house-type. The difficulties were to get hold of tenants before they bought furniture, and to counteract the publicity of commercial firms. ${ }^{129}$

Womersley worried about tenants' capacities 'to ward off the temptations of leisure', and was concerned that tenants develop habits of 'rational' recreation. With echoes of Ruskin, he hoped that 'once we have regained our sense of values in regard to the worth of manual labour, [tenants] will become proficient in making things'. This influential policy advisor and avant garde architect of thousands of Sheffield's homes, greeted affluence for the lower brackets with anxiety:

The challenge today is not to remain sufficiently healthy to earn a living and keep out of the poor house but to learn to develop one's talents so that ever-increasing leisure hours may be used profitably and not frittered away in idleness and mischief. The present day challenge may well prove to be the more difficult of the two. ${ }^{330}$

The model of the free consuming citizen, whose happiness depended on their ability to engage with the commercial domain, to exercise choice, and express their personality free of constraint in their home, could only ever be partially extended to those renting their homes from the state, who often remained subject to an alternative set of strictures based on public sector moralism and paternalism. Not all consuming citizens, it seems, were created equal.

128 TNA:PRO, HLG, 37/203, Lewis Womersley, 'Draft Report', February 1961, 2-3. At Sheffield Womersley was responsible for what is now Europe's largest listed building, the Park Hill housing development.

129 TNA:PRO, HLG, 37/198, Oral Evidence of Aycliffe DC, 6 April 1960.

130 TNA:PRO, HLG, 37/203, Lewis Womersley, 'Draft Report', February 1961, 1-2. 


\section{Conclusion}

The purpose of this article has been to highlight how rapidly and profoundly the logics of mass consumerism reshaped the models of social need and individual rights upon which post-war welfare provisions were based, and to reflect upon some of the implications of this for the shifting relationship between the state, the market, and the individual in twentieth-century Britain. Through an empirically-grounded analysis of one area of social policy it has identified some of the concrete historical processes by which the post-war categories of citizen and consumer were elided; showing how consumerist notions of the individual transformed the ways in which public officials conceived of the citizen-subject and their own duties towards this figure, and tracing corresponding changes in the practices and make-up of public governance which were produced by a recasting of each citizens' needs in terms of their consuming desires. Through mundane debates about the provision of fridges, appropriate heating systems, or how to accommodate 'the teenager', we can see real shifts in the relationship between the state and the individual, and begin to refine grand narratives of consumer society and consumercitizenship with empirical detail.

Parker Morris's deliberations reveal that, once the consuming practices of each citizen were constructed as central to health and happiness within official discourse, political attention was refocused on the figure of the individual, and on their subjective needs and desires. In the field of housing provision, this person-centred approach led not just to an acceptance of material changes in standards of living, but to an acknowledgement of the psychological and expressive comforts which affluent domesticity could offer the individual. Indeed, Parker Morris's recognition of the psycho-social functions of consumption in the home-as a means of expressing one's selfhood and achieving a sense of fulfilment—prefigures the academic identification of 'active consumption' which has occupied such a central place in consumer scholarship since the interventions of Birmingham School theorists. Such an approach to welfare 
provision led to the elevation of individual over familial needs, and we can observe corresponding changes in domestic space and technologies which privileged the privacy and expressive needs of the individual rather than the cohesion of the family unit. This individuation extended to segmenting the family into different types of consuming subject, such as the teenager and the consumer housewife, with their own personalised needs and spatial requirements within the home. ${ }^{131}$ In the case of women, a highly-individualist model of the housewife's needs emerged in which, for all its deeply patriarchal assumptions, it was recognised that women had a legitimate right to make their own choices and could expect to take pleasure from acts of consumption and leisure within the home. In a recent intervention in this journal, Robinson et al have proposed 'the rise of popular individualism' as an organising metanarrative with which to reassess our chronologies of post-war social and political change. ${ }^{132}$ The proposal has much to recommend it, but the authors' suggestion that the substantive political impacts of rising individualism began to be felt in the 1970s is complicated by the evidence presented here, which points to an intensely consumer-driven individualism transforming political norms and public policy as early as the 1950s. The trajectories sketched here of affluent domesticity, homeownership, appeals to the female consumer, and the rise of the teenager, indicate that the 1950s marked a moment in which patterns of consumer-driven social change which had their origins in the interwar period intensified to the extent that they fundamentally reshaped the bases of postwar politics and governance. ${ }^{133}$

The Parker Morris moment is therefore significant in the entanglement of citizenship with consumerism, and in the rise of individualism. It is also significant in understanding what James Vernon calls 'the brief life of social democracy', and it is suggested here that that life may

\footnotetext{
${ }^{131}$ On the post-war development of market segmentation in the US see Lizabeth Cohen, A Consumers' Republic: The Politics of Mass Consumption in Postwar America (New York, 2004), 292-331.

132 Robinson et al, 'Telling Stories about Post-war Britain'.

${ }^{133}$ On the impact of consumerism on post-war party politics see Lawrence Black, Redefining British Politics:

Culture, Consumerism and Participation, 1954-70 (Basingstoke, 2010).
} 
have been briefer than is conventionally imagined. Although the idea of 1979 as a dramatic break point between post-war social democracy and market-oriented neoliberalism has been largely abandoned, it is nonetheless conventional to view the foundations of social democracyuniversal welfare and the mixed economy—as holding firm until the late-1960s or 1970s. ${ }^{134}$ Yet Parker Morris demonstrates that, less than fifteen years after 1945, public policy-makers had come to accept marketised consumption as crucial to the satisfaction of citizens' needs, and were proposing regulatory models which would encourage and enable individuals' engagement with the commercial domain. Furthermore, in addition to recognising the importance of consumerism to individual fulfilment, the elevation of consumer choice and commercial modes of provision entailed a tacit acceptance that universal, socialised, forms of provision could never be a desirable alternative to the private sector. The emphasis on individual choice and direct consultation with citizens challenged the basis of standardised, expert-led, welfare provision, and valorising marketised forms of consumption shifted political and intellectual authority from the sphere of public governance to the commercial domain. Read alongside the simultaneous flourishing of owner-occupation, Parker Morris's consumerist logics contributed to the abandonment of collectivist aspirations in housing provision and the concurrent residualisation of social housing as a special needs service for those incapable of securing private homes. ${ }^{135}$

For the recipients of state housing the effects of these shifts were contradictory. On the one hand recasting the council tenant as the consumer of a social service prompted new forms of direct consultation and encouraged housing authorities to be more responsive to tenants' views and demands. ${ }^{136}$ On the other hand the attempt to enshrine higher material and

\footnotetext{
${ }^{134}$ See for example Vernon's own account, 'Roundtable: Twentieth-Century British History in North America', 409.

${ }^{135}$ Ben Jones, 'Slum Clearance, Privatization and Residualization: the Practices and Politics of Council Housing in Mid-twentieth-century England', Twentieth Century British History $21: 4$ (2010), 510-539.

${ }^{136}$ Peter Shapely, 'Tenants Arise! Consumerism, Tenants and the Challenge to Council Authority in Manchester, 1968-92', Social History 31:1 (2006), 60-78.
} 
psychological standards of comfort for those renting their homes from the state provoked opposition and unease from some quarters, and exposed the persistence of Edwardian moral geographies of class, poverty and individual responsibility within post-war welfare systems. This was manifested both in outright hostility to council tenants enjoying the fruits of affluence, and more subtly in paternalist anxieties about tenants' exposure to the seductions and temptations of commercial culture. More broadly, the privileging and normalising of home-ownership as the ideal mode of tenure marked out the council tenant as a 'flawed consumer' of housing, incapable of participating fully in this important sphere of post-war cultural politics. ${ }^{137}$

Parker Morris was thus fraught with ambivalence, both in its aims and its impact, and the purpose of this discussion has been to link these uncertainties to wider tensions at the heart of the post-war settlement. The elision of social democratic citizenship with consumerist selfhood was highly unstable, containing as it did some basic contradictions between public and private systems of provision, between universalism and individualism, and between competing models of citizens' 'needs'. Nonetheless, Parker Morris shows that we can track the political implications of affluence and mass consumerism through specific areas of social policy, and identify marketised logics and imperatives pervading norms of governance at the height of the supposed social democratic consensus. Indeed, the case points to a less binary and more evolutionary transition from post-war welfarism to market-oriented 'neoliberalism' by showing how social democratic aspirations to guarantee the emotional well-being of each citizen led public officials to cede political authority to the commercial domain once it had been established that the market was more effective at servicing consumer desire. In this way, the new political formations which took shape in the latter part of the century were in part a product of the tensions and instabilities created by the post-war attempt to harness social democracy with affluence. It would be

\footnotetext{
${ }^{137}$ For an account of the tenant as a 'flawed consumer' of present day housing see Lynda Cheshire, Peter Walters \& Ted Rosenblatt, 'The Politics of Housing Consumption: Renters as Flawed Consumers on a Master Planned Estate', Urban Studies 47:12 (2010), pp. 2597-2614.
} 
worthwhile tracing the impact of affluence and consumerism on other areas of post-war governance and social policy in order to further investigate how far the dynamic sphere of individual consumption served to unsettle the post-war settlement. 